\title{
PEMBUATAN MINUMAN KESEHATAN BERBASIS HERBAL UNTUK WARGA DESA KANDANGAN, KECAMATAN KANDANGAN, KABUPATEN KEDIRI
}

\author{
Oleh:
Tukiran $^{1}$, Suyatno $^{2}$, Nurul Hidajati \\ 1,2,3,4 Jurusan Kimia FMIPA Unesa \\ ${ }^{1}$ tukiran@unesa.ac.id
}

\begin{abstract}
Abstrak
Desa Kandangan, merupakan salah satu desa di kecamatan Kandangan, kabupaten Kediri dimana sebagian warganya bekerja sebagai petani, buruh tani, tukang kayu, tukang batu, kuli bangunan, penjual sayur keliling, membuka warung makanan dan merajang. Sementara itu sebagian besar ibu rumah tangganya tidak bekerja karena mengurus pekerjaan rumah tangga. Sebagian dari mereka ada sebagai pembantu rumah tangga, buruh cuci dan seterika, serta berjualan aneka kebutuhan sehari-hari di rumah (merajang). Salah satu jenis pelatihan dari PKM yang diberikan adalah pelatihan pembuatan minuman kesehatan berbasis herbal berbentuk cair, mencakup sirup empon-empon, minuman alang-alang, dan beras kencur yang siap dijual di warung dan toko jamu. Kegiatan PKM ini telah dilaksanakan pada bulan Agustus 2018 dengan melibatkan 11 orang ibu rumah tangga desa Kandangan yang diawali dengan pemaparan materi pelatihan oleh Tim PKM, dilanjutkan dengan pendampingan praktek pembuatan minuman kesehatan berbasis herbal, dan diakhiri dengan refleksi/umpan balik serta pemberian angket. Target kegiatan PKM ini adalah meningkatnya keterampilan ibu-ibu rumah tangga peserta pelatihan dalam pembuatan minuman kesehatan berbasis herbal. Adapun hasil angket dapat diketahui bahwa kegiatan PKM dinyatakan telah berjalan dengan baik serta telah mampu memberikan pemahaman dan penguatan akan keterampilan dalam membuat minuman kesehatan berbasis herbal bagi peserta.
\end{abstract}

Kata Kunci: Pelatihan, minuman kesehatan berbasis herbal, sirup empon-empon, minuman alang-alang, beras kencur

\begin{abstract}
Kandangan Village, is one of the villages in Kandangan sub-district, Kediri where some of its citizens work as farmers, farm laborers, carpenters, masons, construction workers, vegetable vendors, open food stalls and chop. Meanwhile, most of the housewives do not work because they take care of housework. Some of them are housemaids, washing and ironing workers, and selling various daily necessities at home (chopping). One type of training from the PKM given was a training in making liquid-based herbal health drinks, including syrup empon-empon, minuman alang-alang, and beras kencur which are ready for sale in "café" and herbal shops. This PKM activity was carried out in August 2018 involving 13 housewives from Kandangan village, which began with the presentation of training materials by the PKM Team, followed by assistance in the practice of making herbal-based health drinks, and ended with reflections/feedback and giving questionnaires. The target of this PKM activity is the increasing skills of housewives in training in making herbal-based health drinks. The results of the questionnaire can be seen that PKM activities are declared to have gone well and have been able to provide understanding and strengthening skills in making herbal-based health drinks for participants.
\end{abstract}

Keywords: Training, herbal-based health drinks, syrup empon-empon, minuman alang-alang, beras kencur

\section{PENDAHULUAN}

Desa Kandangan, merupakan salah satu desa di kecamatan Kandangan, kabupaten Kediri yang dipimpin seorang kepada desa yang bernama Fatchur Roziq, S.Ag.,S.Pd. Desa ini dibatasi oleh sebelah utara desa Kasreman, sebelah selatan desa Sukosari, sebelah timur desa Banaran, dan sebelah barat desa Klampisan. Di desa tersebut sudah berdiri perkantoran, pertokoan, bank, sekolah/PT, pondok pesantren, pasar, rumah makan, bengkel, dan jenis-jenis usaha lainnya. Sebagian warga desa tersebut bekerja sebagai petani, buruh tani, tukang kayu, tukang batu, kuli bangunan, penjual sayur keliling, membuka warung makanan dan merajang. Sementara itu sebagian besar ibu rumah tangganya tidak bekerja karena mengurus pekerjaan rumah tangga. Sebagian dari mereka ada yang bekerja sebagai 
pembantu rumah tangga, buruh cuci dan seterika, serta berjualan aneka kebutuhan sehari-hari di rumah (merajang). Dengan demikian, sebagian besar warga memiliki penghasilan yang pas-pasan untuk memenuhi kebutuhan hidup.

Upaya pelatihan guna meningkatkan keterampilan warga desa Kandangan sangat diperlukan untuk meningkatkan pendapatan ekonomi keluarganya. Salah satu jenis pelatihan yang dapat diberikan adalah pelatihan pembuatan minuman kesehatan berbasis herbal berbentuk cair. Jenis minuman tersebut memiliki potensi ekonomi untuk meningkatkan penghasilan keluarga. Minuman kesehatan berbentuk cair yang akan dilatihkan mencakup sirup emponempon, minuman alang-alang, dan beras kencur yang siap dijual di warung dan toko jamu. Sirup empon-empon dapat dijajakan setiap saat baik dalam keadaan dingin maupun panas. Mengingat sirup emponempon cukup tahan lama, maka jangkauan pemasarannya bisa lebih luas. Disisi lain, minuman alang-alang adalah suatu terebosan baru yang relatif belum tahu dan banyak diproduksi dan dikonsumsi oleh masyarakat. Alang-alang merupakan sebuah tanaman yang banyak dijadikan sebagai minuman lantaran memiliki khasiat dan manfaat.

Kegiatan PKM ini diharapkan dapat mencapai target sebagai berikut:

1. Meningkatkan keterampilan ibu rumah tangga warga Desa Kandangan, Kec. Kandangan, Kediri dalam membuat minuman kesehatan berbasis herbal. Di akhir kegiatan pelatihan ini diharapkan minimal $80 \%$ peserta pelatihan memiliki keterampilan pembuatan minuman kesehatan berbasis herbal dengan kategori minimal baik.

2. Mendapatkan respon positif dari para ibu rumah tangga warga desa Kandangan, Kec. Kandangan, Kediri terhadap kegiatan pelatihan pembuatan minuman kesehatan berbasis herbal dengan kategori minimal baik.

\section{METODE}

Tahapan pelatihan pembuatan minuman kesehatan berbasis herbal untuk membekali keterampilan para ibu rumah tangga di Desa Kandangan adalah sebagai berikut:

1. Membuat atau menyiapkan buku panduan pembuatan minuman kesehatan berbasis herbal
2. Pemaparan materi pembuatan minuman kesehatan berbasis herbal, wawasan wirausaha, manajemen usaha, dan teknik pengemasan produk oleh Tim PKM

3. Memberikan contoh pembuatan minuman kesehatan berbasis herbal dengan melibatkan peserta pelatihan menggunakan bahan-bahan yang telah disediakan

4. Praktek mandiri pembuatan minuman kesehatan berbasis herbal yang dilakukan oleh ibu rumah tangga peserta pelatihan. Pada tahap ini peserta pelatihan dibagi menjadi 2 kelompok (tiap kelompok beranggotakan 5-6 orang) dan masingmasing kelompok melakukan praktek pembuatan sirup empon-empon, wedang alang-alang dan minuman beras kencur. Keterampilan peserta di tiap kelompok diukur menggunakan Lembar Penilaian Kinerja.

5. Melakukan refleksi/umpan balik dan masukan/opini/pendapat dan saran para peserta pelatihan tentang hasil pelatihan yang telah dilaksanakan, diikuti pemberian Lembar Angket untuk mengetahui respon peserta pelatihan terhadap kegiatan pelatihan yang telah dilakukan

\section{HASIL DAN PEMBAHASAN}

Kegiatan PKM ini disepakati bersama dan dilaksanakan di Balai Kelurahan Desa Kandangan, Kabupaten Kandangan, Kediri pada tanggal 4 Agustus 2018 mulai pagi jam 08.00 sd 13.00 dengan diikuti 11 peserta dengan usia berkisar antara 30-40 tahun. Berikut adalah nama-nama peserta yang ikut kegiatan PKM: 1) Yeni Susanti, 2) Susian, 3) Sunah, 4) Purwati, 5) Sri Rahayu, 6) Yuliani, 7) Murdiyah, 8) Indah, 9) Ismiati, 10) Nyoto Prayitno, dan 11) Wahyudiono.

1. Pelaksanaan

Berikut adalah kegiatan PKM yang dilaksanakan mulai dari:

a. Sambutan oleh Kepala Desa Kandangan, Kabupaten Kandangan, Kediri dan Pimpinan Jurusan Kimia, FMIPA, Unesa Surabaya.

b. Pemberian Materi PKM oleh Ketua Pelaksana PKM (Prof. Dr. Tukiran, M.Si.) dan Praktek Membuat Minuman Kesehatan Berbasis Herbal oleh Peserta Didampingi Tim Pelaksana PKM 


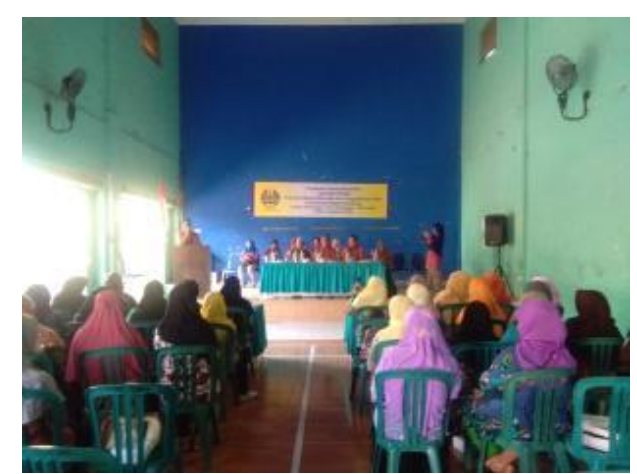

Gambar 1. Kepala Desa Memberi Sambutan dan Sekaligus Membuka Resmi Acara PKM

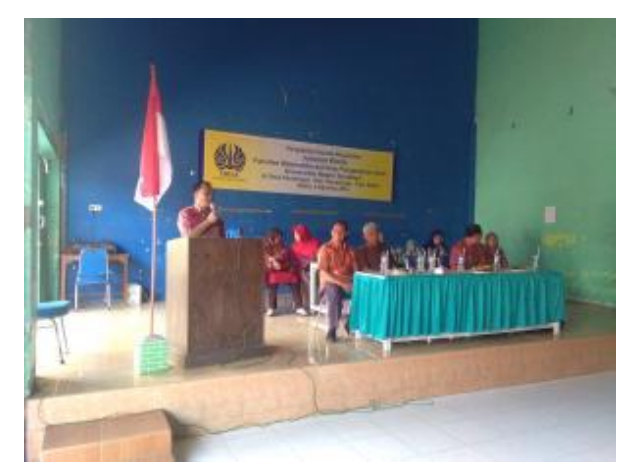

Gambar 2. Pimpinan Jurusan Memberi Sambutan untuk Memberikan Arahan tentang PKM

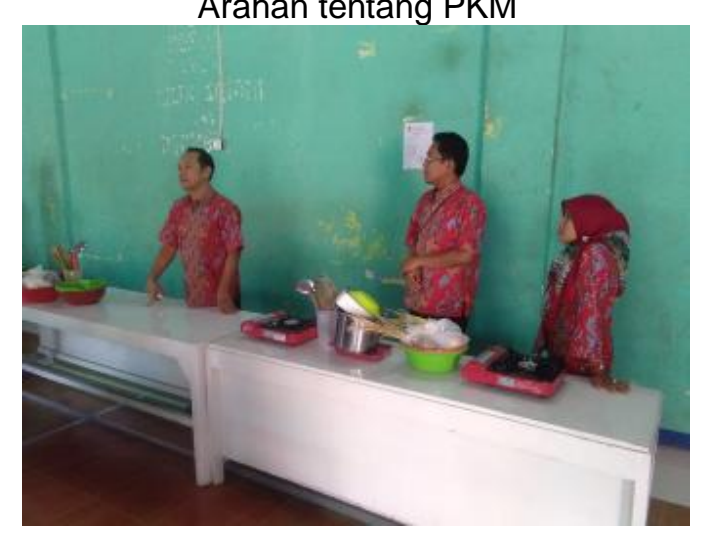

Gambar 3. Ketua Pelaksana PKM Sedang Memberi Materi PKM

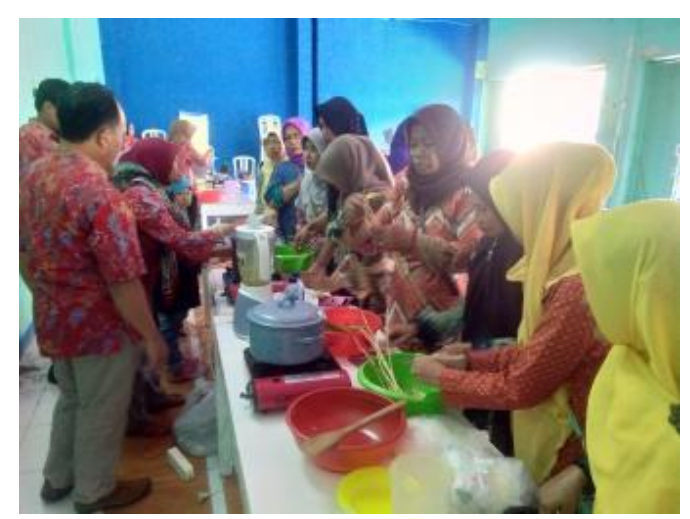

Gambar 4. Para Peserta Siap-siap Praktek Membuat Minuman Berbasis Herbal

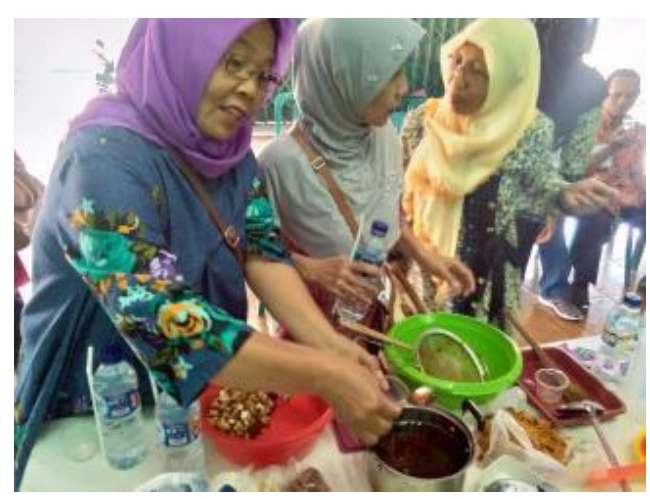

Gambar 5. Peserta dengan Serius Menyelesaikan Pembuatan Minuman Herbal

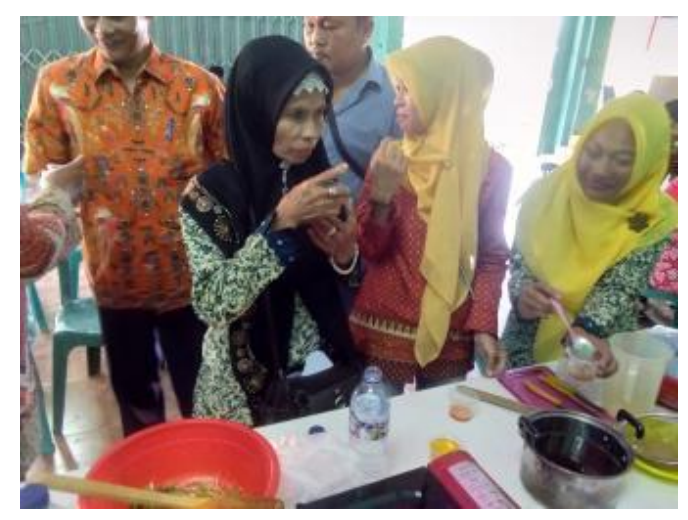

Gambar 6. Peserta mencoba Mencicipi Minuman Herbal yang telah Dibuatnya 
2. Analisis Keterampilan Hasil PKM

Untuk mengetahui sejauhmana pemberdayaan masyarakat Kandangan dalam memenuhi target capaiannya, yaitu mereka memiliki keterampilan pembuatan minuman kesehatan berbasis herbal berbentuk cair mencakup sirup emponempon (Tabel 1), wedang alang-alang (Tabel 2), dan minuman beras kencur (Tabel 3) dilakukanlah penilaian terhadap kinerja mereka dan hasilnya dapat ditunjukkan adalah sebagai berikut. Berikut adalah kegiatan PKM yang dilaksanakan mulai dari:

Tabel 1. Penilaian Keterampilan Pembuatan Sirup Empon-empon

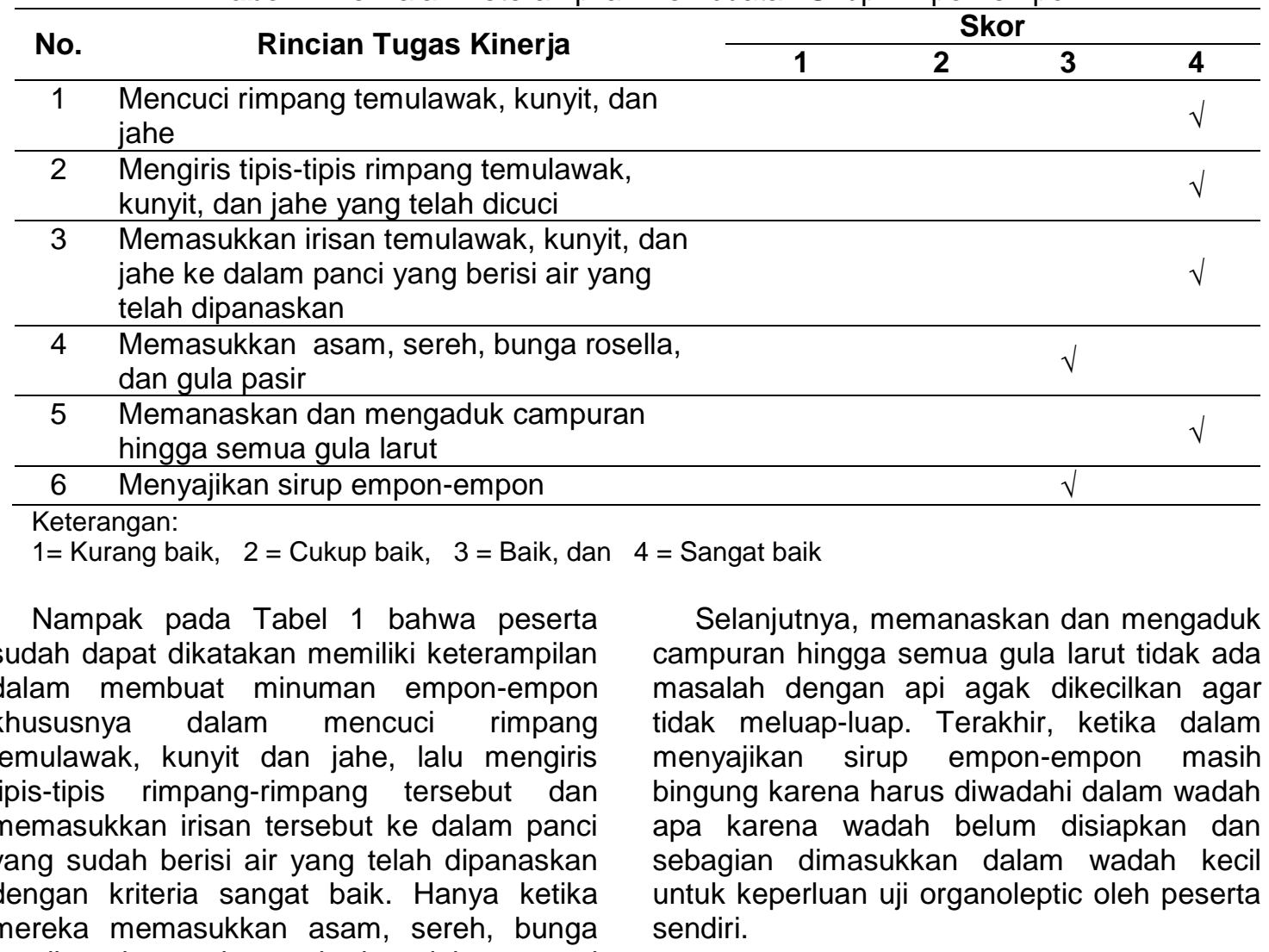


Tabel 2. Penilaian Keterampilan Pembuatan Wedang Alang-alang

\begin{tabular}{clcc}
\hline \multirow{2}{*}{ No. } & \multicolumn{1}{c}{ Rincian Tugas Kinerja } & \multicolumn{3}{c}{ Skor } \\
\cline { 2 - 4 } 1 & $\begin{array}{l}\text { Mencuci alang-alang dan daun pandan } \\
\text { wangi hingga bersih }\end{array}$ & $\mathbf{3}$ & $\mathbf{4}$ \\
\hline 2 & Membakar rimpang jahe dan dimemarkan & $\sqrt{ }$ & \\
\hline 3 & Mememarkan batang kamijoro & & $\sqrt{ }$ \\
\hline 4 & $\begin{array}{l}\text { Mencampur semua bahan tersebut menjadi } \\
\text { satu, letakkan di satu wadah }\end{array}$ & $\sqrt{ }$ \\
\hline 5 & $\begin{array}{l}\text { Merebus semua bahan tersebut dalam air } \\
\text { putih hingga mendidih dan mulai } \\
\text { mengeluarkan aroma jahe }\end{array}$ & $\sqrt{ }$ \\
\hline 6 & $\begin{array}{l}\text { Mengaduk merata untuk melarutkan } \\
\text { gulanya, cicipi juga sedikit demi sedikit jika } \\
\text { kurang manis tinggal tambahkan gula } \\
\text { hingga mendapatkan rasa yang pas di lidah } \\
\text { kamu }\end{array}$ & $\sqrt{ }$ & \\
\hline 7 & $\begin{array}{l}\text { Wedang alang-alang tradisional siap } \\
\text { dinikmati }\end{array}$ & \\
\hline $\begin{array}{l}\text { Keterangan: } \\
1=\text { Kurang baik, 2 = Cukup baik, 3 = Baik, dan 4 = Sangat baik }\end{array}$ & \\
\end{tabular}

Dari Tabel 2 nampak bahwa secara keseluruhan peserta telah mampu dan terampil dalam Pembuatan Wedang Alangalang dengan kriteria sangat baik. Hanya saja kegiatan mencuci alang-alang dan daun pandan wangi hingga bersih tidak dilakukan dengan baik karena saat pelaksanaan, air agak sulit didapat akibat berbarengan dengan proses pembangunan gedung di sebelah (kriteria baik). Membakar rimpang jahe dan dimemarkan juga mendapatkan penilaian dengan kriteria baik karena proses membakar agak kesulitan mau menggunakan sumber api kompor gas atau dari luar.
Selanjutnya, pada Tabel 3 terlihat bahwa secara umum peserta memiliki keterampilan dalam pembuatan beras kencur dengan kriteria sangat baik, kecuali merendam beras yang sudah dicuci tadi selama kurang lebih 4 jam. Padahal, kenyataannya tidak direndam selama 4 jam (kira-kira 1 jam) karena mepetnya waktu pelaksanaan yang disediakan oleh panitia (dari kelurahan), namun tidak berpengaruh secara signifikan terhadap kualitas produk beras kencur. Jahe dan kunyit yang ikut direbus tadi digiling bersama dengan kencur dan beras hingga halus, nampaknya ada kebingungan (sempat terhenti) karena alat mixernya cuma satu dan harus menunggu giliran pemakaian mixer tersebut. 
Tabel 3. Penilaian Keterampilan Pembuatan Beras Kencur

\begin{tabular}{|c|c|c|c|c|}
\hline \multirow{2}{*}{ No. } & \multirow{2}{*}{ Rincian Tugas Kinerja } & \multicolumn{3}{|c|}{ Skor } \\
\hline & & 1 & 2 & 4 \\
\hline 1 & Mencuci beras minimal 2 kali pencucian & & & $\sqrt{ }$ \\
\hline 2 & $\begin{array}{l}\text { Merendam beras yang sudah dicuci tadi } \\
\text { selama kurang lebih } 4 \text { jam }\end{array}$ & & $\sqrt{ }$ & \\
\hline 3 & $\begin{array}{l}\text { Panaskan } 6 \text { gelas air dan masukkan gula } \\
\text { jawa, asam jawa, jahe dan kunyit. Masak } \\
\text { hingga mendidih }\end{array}$ & & & $\sqrt{ }$ \\
\hline 4 & $\begin{array}{l}\text { Setelah mendidih, saring air rebusan tadi } \\
\text { dan sisihkan }\end{array}$ & & & $\sqrt{ }$ \\
\hline 5 & $\begin{array}{l}\text { Jahe dan kunyit yang ikut direbus tadi } \\
\text { digiling bersama dengan kencur dan beras } \\
\text { hingga halus }\end{array}$ & & $\sqrt{ }$ & \\
\hline 6 & $\begin{array}{l}\text { Setelah semua bahan halus, masukkan } \\
\text { bahan tersebut ke dalam saringan kapasitas } \\
\text { besar dan siram dengan air rebusan tadi } \\
\text { sedikit demi sedikit sambil diperas }\end{array}$ & & & $\sqrt{ }$ \\
\hline 7 & $\begin{array}{l}\text { Apabila dirasa ramuan kurang manis, dapat } \\
\text { ditambahkan dengan gula pasir atau madu }\end{array}$ & & & $\sqrt{ }$ \\
\hline
\end{tabular}

3. Pelaksanaan

Setelah kegiatan pelatihan dan pendampingan selesai dilakukan, peserta diberikan lembar angket respon terhadap pelaksanaan PKM. Hal ini bertujuan untuk melihat sejauhmana kegiatan tersebut dikatakan telah berjalan dengan baik serta telah mampu memberikan pemahaman dan penguatan akan keterampilan dalam membuat minuman kesehatan berbasis herbal bagi peserta. Hasil analisis data angket respon terhadap 11 peserta yang diperoleh dapat dilaporkan sebagaimana tercantum pada Tabel 4 berikut.

Tabel 4. Analisis Hasil Angket Respon Terhadap Pelaksanaan PKM Kandangan Kediri

\begin{tabular}{|c|c|c|}
\hline No & Aspek & Keterangan \\
\hline 1 & $\begin{array}{l}\text { Mengapa Saudara mengikuti kegiatan } \\
\text { pelatihan ini? } \\
\text { a. Diperintahkan oleh perangkat RT/ RW. } \\
\text { b. Mengikuti ajakan teman } \\
\text { c. Ingin memperoleh sumbangan } \\
\text { d. Ingin menambah pengetahuan dan } \\
\text { keterampilan }\end{array}$ & $\begin{array}{l}\text { Semuanya ( } 100 \%) \text { menjawab d. Ingin } \\
\text { menambah pengetahuan dan } \\
\text { keterampilan }\end{array}$ \\
\hline 2 & $\begin{array}{l}\text { Bagaimana sikap keluarga dengan } \\
\text { keikutsertaan Saudara pada kegiatan } \\
\text { pelatihan ini? } \\
\text { a. Sangat mendukung } \\
\text { b. Mendukung } \\
\text { c. Kurang mendukung } \\
\text { d. Tidak mendukung }\end{array}$ & $\begin{array}{l}\text { Semuanya (100\%) menjawab a. Sangat } \\
\text { mendukung }\end{array}$ \\
\hline 3 & $\begin{array}{l}\text { Menurut pendapat Saudara, bagaimana } \\
\text { penyelenggaraan kegiatan pelatihan ini? } \\
\text { a. Sangat baik } \\
\text { b. Baik } \\
\text { c. Kurang baik } \\
\text { d. Tidak baik }\end{array}$ & $\begin{array}{l}9 \text { orang menjawab a. sangat baik }(81,8 \%) \\
\text { dan sisanya menjawab b. baik. }\end{array}$ \\
\hline
\end{tabular}




\begin{tabular}{|c|c|c|}
\hline No & Aspek & Keterangan \\
\hline 4 & $\begin{array}{l}\text { Apakah kegiatan pelatihan ini menarik bagi } \\
\text { Saudara? } \\
\text { a. Sangat menarik } \\
\text { b. Menarik } \\
\text { c. Kurang menarik } \\
\text { d. Tidak menarik }\end{array}$ & $\begin{array}{l}10 \text { orang menjawab a. sangat menarik } \\
(90.9 \%) \text { dan sisanya } 1 \text { orang }(9,1 \%) \text { yang } \\
\text { menjawab b. menarik. }\end{array}$ \\
\hline 5 & $\begin{array}{l}\text { Apakah kegiatan pelatihan ini bermanfaat } \\
\text { bagi Saudara? } \\
\text { a. Sangat bermanfaat } \\
\text { b. Bermanfaat } \\
\text { c. Kurang bermanfaat } \\
\text { d. Tidak bermanfaat }\end{array}$ & $\begin{array}{l}\text { Semuanya (100\%) menjawab a. sangat } \\
\text { bermanfaat. }\end{array}$ \\
\hline
\end{tabular}

Bagaimana pengetahuan dan keterampilan Saudara setelah mengikuti kegiatan pelatihan ini?

6 a. Sangat meningkat

b. Meningkat

c. Kurang meningkat

d. Tidak ada perubahan

Apakah Saudara yakin dapat melanjutkan hasil kegiatan pelatihan ini di rumah?

7
a. Sangat yakin
b. Yakin
c. Kurang yakin
d. Tidak yakin

Apakah sebelumnya Saudara pernah mengikuti kegiatan pelatihan semacam ini?

8 a. Sangat sering
b. Sering
c. Jarang
d. Tidak pernah

Bagaimana tanggapan anda terhadap materi yang disampaikan narasumber?

$9 \quad$ a. Sangat mudah dipahami

b. Mudah dipahami

c. Cukup mudah dipahami

d. Sulit dipahami

Manakah di antara kegiatan pelatihan hari ini yang Saudara sukai?
a. Pembuatan minuman kesehatan Empon-empon
10 b. Pembuatan minuman kesehatan wedang alang-alang
c. Pembuatan minuman kesehatan beras kencur
d. Semua materi tidak saya sukai

Tuliskan saran Saudara berkaitan dengan

11 kegiatan pelatihan pada hari ini!
Sebanyak 7 orang $(63,6 \%)$ menjawab meningkat dan sisanya $36,4 \%$ menjawab sangat bermanfaat.

Sebanyak 5 orang $(45,5 \%)$ yang menjawab a. sangat yakin dan 6 orang $(54,4 \%)$ menjwab b. yakin.

1.Sebanyak 7 orang $(63,6 \%)$ menjawab d. tidak pernah.

2. Ada 2 orang $(18,2 \%)$ yang menjawab $b$. sering

3. Ada 2 orang $(18,2 \%)$ yang menjawab c. jarang.

1. Ada 6 orang $(54,5 \%)$ menjawab a. sangat mudah dipahami.

2. Ada 4 orang $(36,4 \%)$ menjawab b. mudah dipahami.

3. Ada 1 orang $(9,1 \%)$ yang menjawab c. cukup mudah dipahami.

1. Ada 4 orang $(36,4 \%)$ yang menyukai semuanya (a, b, dan $\mathrm{c}$ )

2. Ada 4 orang $(36,4 \%)$ juga yang menyukai bagian a.

3.Ada 2 orang $(18,1 \%)$ yang menyukai bagian $\mathrm{c}$.

4. Hanya 1 orang $(9,1 \%)$ yang menyukai bagian $b$.

Dari 11 orang hanya ada 9 orang yang telah memberikan saran dan masukan dengan catatannya adalah sebagai berikut:

1. Saya sangat senang dengan pelatihan membuat herbal seperti ini. Terimakasih.

2. Durasi waktu perlu ditambah 
Tukiran, dkk., Pembuatan Minuman Kesehatan ....

\begin{tabular}{|c|c|c|}
\hline No & Aspek & Keterangan \\
\hline & & $\begin{array}{l}\text { 3. Terimakasih atas pelatihannya } \\
\text { semoga bermanfaat dan saya bisa } \\
\text { belajar sehingga bisa menunjang } \\
\text { aktivitas. } \\
\text { 4. Terimakasih telah memberi } \\
\text { pengetahuan yang sangat langka ini. } \\
\text { 5. Tambah sangat semangat untuk } \\
\text { tambah pengalaman. } \\
\text { 6. Untuk pelatihan semacam ini harusnya } \\
\text { waktunya agak lama, biar bisa } \\
\text { maksimal. } \\
\text { 7. Sering-sering mengadakan kegiatan } \\
\text { seperti ini. } \\
\text { 8. Sering2lah mengadakan pelatihan } \\
\text { seperti ini. } \\
\text { Durasi waktu kurang sehingga belum ada } \\
\text { pengenalan empon2 dan macam } \\
\text { kegunaan. }\end{array}$ \\
\hline
\end{tabular}

\section{SIMPULAN DAN SARAN}

Berdasarkan pada hasil kegiatan yang telah dilakukan dapat disimpulkan bahwa pelaksanaan PKM "Pembuatan Minuman Kesehatan Berbasis Herbal" ini telah berjalan dengan baik dan lancar. Hal ini dapat diindikasikan dari keberhasilan peserta mampu membuat dengan terampil minuman kesehatan tersebut dengan baik dan lancar. Adapun saran yang dapat diajukan adalah sebaiknya pihak mitra diberi kelonggaran waktu untuk kegiatan PKM tersebut, misal 3 kali selama pelatihan agar mampu menyerap ilmu tentang jenis/macam minuman kesehatan berbasis herbal dan kegunaannya serta mampu mengembangluaskan dengan baik di kemudian hari

\section{DAFTAR PUSTAKA}

Anonim. (2018). Wedang Alang-alang. https://id.tastemade.com/videos/wedangalang-alang. Diakses pada tanggal 25 April 2018.

Anonim. (2018). Manfaat Beras Kencur dan Bagaimana Cara Membuat Jamu Beras Kencur?

http://sehatunikmat.blogspot.co.id/2016/04 l.html. Diakses tanggal 25 April 2018.

Anonim. (2018). Minuman racikan empon empon khas tradisional menyehatkan bagi tubuh.

http://www.pastvnews.com/kuliner/minuma n-racikan-empon-empon-khas-tradisionalmenyehatkan-bagi-tubuh.html. 